\title{
Metadata, langtidsbevaring af e-arkivalier og LO-fagforbundenes elektroniske informationssystemer
}

\author{
Af Jesper Jørgensen
}

\begin{abstract}
Med udgangspunkt $i$ begreberne metadata og langtidsbevaring af e-arkivalier og af resultaterne af en spørgeskemaundersøgelse af de danske LO-fagforbunds e-systemer forsøges det at besvare problemstillingerne: Lever forbundene op til standarderne? Og kan der forventes at vare tilstroekkelig metadata til at sikre en tilfredsstillende langtidsbevaring af forbundenes e-arkivalier? Af undersøgelsen tegner der sig for det forste et billede af, at de mindre forbund endnu ikke benytter sig af e-systemer; at de mellemstore forbund har udvidede e-registre i form af medlems-og a-kassesystemer; og at de store forbund har EDH/ESDH. For det andet kan man konkludere, at der på noer et par store forbund er en klar tendens til at vaelge standardløsninger ( $f x$ FESD-systemer), der må vurderes som den bedste garant for tilstrcekkelig metadata. Til gengaeld forfølges en anden bevaringsstrategi, end den der anbefales på området, hvilket kan gøre bevaringen af den fremtidige, historiske kildemasse vanskelig.
\end{abstract}

Jesper Jørgensen, arkivar, cand.mag. og MA, Arbejdermuseet \& Arbejderbevagelsens Bibliotek og Arkiv,jesper.joergensen@arbejdermuseet.dk.

\section{Indledning}

Kulturministeriets Privatarkivudvalg under ledelse af Statens Arkiver har i september 2007 udarbejdet en redegørelse om indsamling, bevaring og tilgængeliggørelse af private e-arkivalier. Hovedpointen er, at vi står over for store problemer, der skal løses, hvis ikke uerstattelige dele af den danske kulturarv skal gå til grunde. Der er så at sige 'udfordringer' hele vejen rundt. Arkivinstitutionerne mangler viden, praktiske erfaringer og resurser. Og mindst lige så slemt; de private arkivskabere, der formentlig skal betale gildet, mangler motivationen for at gå ind i $\operatorname{det}(R e$ degørelse til Privatarkivudvalget, 15.9.2007).

Arbejdermuseet \& Arbejderbevægelsens Bibliotek og Arkiv (herefter ABA), hvor jeg selv er ansat som arkivar, står derfor ikke alene med udfordringerne i forbindelse med langtidsbevaring af elektroniske arkivalier. Problemstillingerne er til gengæld heller ikke nye, da overgangen til elektronisk tekstbehandling allerede tog fart i 1980'erne og blev den dominerende form for tekstproduktion i løbet af 1990'erne, men først i 2007 har ABA modtaget det første e-arkiv i form af et elektronisk dokumenthåndteringssystem (EDH). Derved er udfordringerne for ABA gået fra at være teoretiske til nu også at være praktiske og nærværende.

Selvom vi længe har vidst, at også fagbevægelsen gradvist har taget flere og flere e-systemer i brug $\mathrm{i}$ deres daglige virksomhed, så har vi ikke haft megen eksakt viden om disse systemer og deres indhold. 
Det er der flere gode grunde til, men én af dem er, at ABA ikke tidligere har indhentet den type af viden, da det ikke har været ambitionen at påvirke arkivdannelsen i organisationerne. Problemet er imidlertid, at denne praksis kan have mere vidtrækkende konsekvenser for bevaringen af e-arkiver end for bevaring af papirarkiver, fordi en tilfredsstillende langtidsbevaring af e-arkivalier kræver betydelig mere af organisationerne end tidligere.

De nye krav handler dels om implementering af e-systemer og procedurer for omgangen med disse, hvilket ikke vil blive forfulgt yderligere her. Dels knytter det an til metadata og bevaringsstrategier, der berører den mere tekniske side af sagen og er fokuspunkter her i artiklen. Metadata er en kompleks størrelse og kan bruges i mange sammenhænge. Afgørende er det, at der til e-dokumenter skal være tilknyttet metadata om en række forhold for, at de kan langtidsbevares som e-arkivalier med autenticiteten i behold. Man kan således sige, at metadata er fundamentet i dokumentationen af e-arkiver og e-arkivalier (Hansen, 1999). Uden metadata vil det ikke være muligt at genskabe samt vurdere dokumenterne i deres organisatoriske og historiske sammenhæng. Alternativet er i værste fald, at eftertiden vil stå uden brugbare kilder til fagbevægelsens historie fra midten af 1990'erne og frem.

Sikringen af tilstrækkelig metadata er ikke en opgave, som ABA kan eller skal løfte alene. Der er grund til at have en vis tiltro til, at både producenter af e-systemer, andre dokumentstyrings- og arkivaktører samt vedtagne standarder på området vil påvirke vores arkivskabere i en positiv retning, men vi skal have den fornødne viden for at kunne agere i feltet og for at kunne tilbyde tilfredsstillende og relevante løsninger. Et skridt på vejen må være, at få overblik over problemets omfang både teoretisk og praktisk. Dernæst må situationen vurderes i forhold til 'best practice' på området, nationalt og internationalt.

Konkret vil jeg her i artiklen, på baggrund af en diskuterende gennemgang af de teoretiske problemstillinger bag begreberne metadata og langtidsbevaring i relation til e-dokumenter/-arkivalier, præsentere resultaterne af en spørgeskemaundersøgelse af LOfagforbundenes e-systemer og forsøge at besvare følgende spørgsmål: 1) Lever LO-fagforbundene op til standarderne på området? 2) Kan der forventes at være tilstrækkelig metadata til at sikre en tilfreds- stillende langtidsbevaring af forbundenes fremtidige e-arkivalier? ${ }^{1}$

\section{Dokumentstyringsmetadata ${ }^{2}$}

Udbredelsen af den elektroniske tekstbehandling har været massiv inden for de sidste 10-15 år. Størstedelen af den dokumentariske information inden for al form for virksomhed skabes i dag i et elektronisk format. Håndteringen af alle disse e-dokumenter har imidlertid ikke fulgt med udviklingen. Alt for mange steder bliver e-dokumenter håndteret efter en ukontrolleret ad hoc-praksis, der ikke tager højde for e-dokumenters særlige egenskaber og behovet for kontrolleret tildeling af metadata. Konsekvensen er mange steder en kaotisk opfyldning af filservere, hvor ukontrollerede kopier og forskellige versioner af dokumenter ligger mellem hinanden, og hvor opbygningen af virksomhedens viden derfor ikke følger mængden af data, der produceres. Med henvisning til den internationale standard for dokumentstyring, ISO 15489, kan dette ikke betragtes som god virksomhedspraksis (Morelli, 2007, s. 17f).

Netop standarder har været svaret på de udfordringer, der er opstået med den øgede produktion af edokumenter. Standarder skulle kunne sikre interoperabilitet og effektiv udnyttelse af altid sparsomme resurser - populært sagt reducere 'genopdagelsen af hjulet'-syndromet (Pember, 2006, s. 23f). Det er dog et forholdsvist nyt fænomen inden for feltet. Først i 2001 lancerede International Organization for Standardization (ISO) ISO 15489, der bl.a. beskriver dokumentets livscyklus, dets karakteristika, autenticitet, pålidelighed, integritet og anvendelse. Ligeledes beskrives processerne bag dokumenthåndteringen: klassifikation, indeksering, tesaurus, opbevaringsperioder, adgang til dokumenter m.m. samt selve systemet bag dokumenthåndteringen. Målet er at sikre kvalitet i virksomheders omgang med dokumenter (Marker, Nymand, Pedersen, 2001). Der er siden hen arbejdet på en standard for dokumentstyringsmetadata, ISO 23081, der refererer til ISO 15489. Indtil videre er der udkommet Part 1: Principles (ISO, 2006) og Part 2: Conceptual and implementation issues (ISO, 2007), der tilsammen ifølge ISO skulle give et godt grundlag for en fornuftig metadataproduktion.

For Danmarks vedkommende behandles standarder for dokumentstyringsmetadata for det offentliges vedkommende gennem FESD-projektet (Fællesof- 
fentlig Elektronisk Sags- og Dokumenthåndtering) under Projekt Digital Forvaltning (Se Om FESD, 12.3.2007). FESD-standarderne baserer sig bl.a. på Noark-4, som jeg vil komme nærmere ind på i analysedelen. På europæisk plan foregår standardiseringsarbejdet i DLM-Forum (Document Lifecycle Management), der er i gang med udviklingen af 2. udgave af 'Model Requirements for the management of electronic documents' (MoReq2), hvorunder krav til metadata figurerer som et selvstændigt kapitel (MoReq2 Scoping Rapport, Version 3, Februar 2006). MoReq inddrages også i FESD.

Kendetegnende for projekterne er, at de bygger på en opfattelse af, at e-dokumentet skal håndteres i e-systemer ved hjælp af bl.a. metadata igennem hele dets livscyklus. Livscyklusopfattelsen relaterer til 'record continuum'-tænkningen, men baserer sig på både kustodiale (custodial) og post-kustodiale principper.

\section{Arkivmetadata}

Ifølge Frank Upward (1996, 1997), der har fået æren for udviklingen og defineringen af begrebet 'records continuum', er der afgørende forskelle på papir- og e-dokumenter/-arkivalier. Tabet af det fysiske dokument gør det nødvendigt, at arkivarer revurderer deres opfattelse af dokumentets natur og dets dokumentariske kvaliteter. Det er, ifølge Upward (1996), nødvendigt at bevæge sig fra en kustodial til en postkustodial strategi:

"This strategy is a departure from the traditional custodial approach taken by archival institutions but recognizes that in the electronic age physical custody is no longer an essential element of preservation strategy. What is essential is for electronic records to be identified, controlled and accessible for as long as they have value to Government and the Community."

I den post-kustodiale tænkning ligger en forestilling om 'record continuum', altså at dokumenter ikke på samme måde som tidligere udtjenes i virksomhedssammenhæng, afleveres på arkiv og skifter karakter bliver et arkivalie til historisk brug (jf. Schellenbergs (1956) distinktion mellem dokumenters primære og sekundære værdier). I stedet lægges der vægt på, at dokumentet ikke skifter karakter, og at der derfor ikke skal skelnes mellem elektronisk sag- og dokumenthåndtering og virtuel arkivering.
Upward (1996) opererer derfor heller ikke med en livscyklusmodel, men med en tid/sted-konstruktion, hvor dokumentets forskellige funktioner i princippet kan udnyttes kontinuerligt. Selvom dette sidste kun delvist er slået igennem (jf. fx navnet DLM-Forum), er der draget den afgørende konsekvens af 'record continuum'-tænkningen, at arkivarbejdet skal sættes i værk langt tidligere i processen, end det før er sket. Faktisk skal arkivarer være med i udviklingen af systemerne for at sikre en tilfredsstillende langtidsbevaring (se også Gilliland-Swetland, 2005, s. 226-229).

Disse nye forudsigelser om konsekvenserne af den såkaldte 2. generation af e-systemer (se også Wallace, 1993) har affødt flere skeptiske kommentarer. Ikke alle inden for arkivverdenen har uden videre villet opgive den traditionelle opfattelse af arkivinstitutionernes og arkivarernes rolle. Især Heather MacNeil (1996) har gjort sig til talsmand for, at der ikke er noget specielt anderledes ved elektronisk arkivmateriale. Hun mener derfor heller ikke, at den nye "metadata systems approach" overflødiggør den traditionelle arkivbeskrivelse. Med henvisninger fra den moderne arkivteoris pionerer Muller, Feith and Fruins Handeleiding voor het Ordenen en Beschrijven van Archiven (1898) til International Council of Archives' (ICA) General International Standard Archival Description (ISAD(G)) (1994) om bl.a. proveniensprincippet argumenterer hun for, at fortalerne for eksistensen af en '2. generation' af dokumenter og systemer glemmer, at der ikke er noget nyt ved behovet for at beskrive konteksten for at forstå dokumenters mening.

Endvidere har hun ikke tiltro til, at e-systemers metadata kan give tilstrækkelig information, fordi de med deres tilknytning til det enkelte element (item)/ system af natur er afskåret fra at give oplysninger på fondsniveau. Hun beskriver forskellen mellem arkivbeskrivelser (arkivmetadata) og metadata (dokumentstyringsmetadata) som forskellen mellem en dagbog og en biografi. Kun den sidste kan løfte sig over daglige liv og analysere det allerede levede liv (MacNeil, 1996, s. 24f).

En tredje interessant indvending er, at ved (også) at opfatte e-systemer som redskaber for arkivformål og derfor forsøge at inkorporere arkivmetadata i e-systemerne, interveneres der direkte i den primære brug af dokumenterne og derved i dokumenternes historiske 
kontekst. Denne indvending er tilsyneladende blevet negligeret - formentlig af praktiske grunde. For hvad er alternativet til at søge indflydelse på e-systemerne? Umiddelbart må konsekvenserne, ved ikke at gøre det, være værre. At vente med at sikre oplysninger om indhold og kontekst til efter e-materialet er afleveret, vurderes som resursemæssigt uoverskueligt selv for de bedst finansierede arkivinstitutioner (Wallace, 1993, s. 106).

Det andet kritikpunkt er siden hen indirekte imødegået ved optagelsen af flere facetter i metadatabegrebet og med udarbejdelsen af ISO 15489 og ISO 23081, der fastsætter en række skrappe krav til metadata vedr. elementers indhold og kontekst på alle aggregeringsniveauer, inkl. hvad der svarer til fondsniveau, over tid. Proveniensbegrebet er i nyere arkivteori blevet udvidet. Med e-arkivalier er det ikke længere tilstrækkeligt at opfatte proveniensen som statisk. Der må anlægges et bredere perspektiv på de processer, der har skabt arkivaliet - et perspektiv, der er åben for flere arkivskabere med flere forskellige roller over for arkivaliet (Hansen, 2007, s. 18).

Til gengæld er der bred enighed om, at $\operatorname{ISAD}(\mathrm{G})$ skal tilpasses de nye elektroniske forhold og suppleres med nye typer af arkivmetadata. Den seneste udgi- velse fra ICA (2005, s. 65) om arkivering af e-dokumenter, der i øvrigt relaterer sig til ISO 15489, ser dette som en udfordring for fremtiden [sic].

Det har imidlertid ikke afholdt Shepherd \& Smith (2000) fra at give et bud på, hvad der kan være mangler i $\operatorname{ISAD}(\mathrm{G})$ for at beskrive e-arkivalier - $\mathrm{i}$ form af elektroniske datasæ ${ }^{3}$ og med fokus på de lavere beskrivelsesniveauer (serie- og sagsniveau). Undersøgelsen går helt ned i detaljerne af $\operatorname{ISAD}(\mathrm{G})$ og dens 26 beskrivelseselementer samt foreslår omskrivninger og suppleringer (se de kursiverede elementer i Figur 1), så de også kan omfavne datasæt.

Uden at gå nærmere ind i de enkelte elementer i figuren, så er det tydeligt, at der i forhold til tidligere anbefales et yderligere fokus på e-arkivaliernes kontekst og struktur for at sikre autenticiteten. Forslagene nåede ikke at blive indarbejdet i 2.-udgaven af $\operatorname{ISAD}(\mathrm{G})$, hvilket illustreres godt ved, at termerne 'digital' og 'electronic' kun figurerer henholdsvis 1 og 2 gange i det 91 sider lange dokument (ICA, 2000).

I forlængelse af Shepherd \& Smiths undersøgelse er der lavet forsøg med at mappe $\operatorname{ISAD}(\mathrm{G})$ med ISO 15489-elementer. Shepherd \& West (2003a, b)

\footnotetext{
3. ELEMENTS OF DESCRIPTION

3.1 Identity Statement Area

3.1.1 Reference code(s)

3.1.2 Title

3.1.3 Dates of creation of the material in the unit of description

3.1.4 Dates of contents of the material in the unit of description

3.1.5 Date of last input

3.1.6 Date of last access

3.1.7 Level of description

3.1.8 Extent of the unit of description (quantity, bulk, or size)

3.2 Context Area

3.2.1 Administrative/biographical history

3.2.2 Aim and purpose

3.2.3 Statement of responsibility

3.2.4 Custodial history

3.2.5 Immediate source of acquisition

3.3 Scope and Content Area

3.3.1 Scope and content/abstract

3.3.2 Appraisal, destruction and scheduling information

3.3.3 Accruals

3.4 Structure Area

3.4.1 Logical structure and schema

3.4.2 The active/working nature of the database

3.4.3 Data capture and validation before tansfer to the archive

3.4.4 Constraints on the data reliability
}
3.5 Conditions af Access and Use Area
3.5.1 Legal status
3.5.2 Access conditions
3.5.3 Copyright/conditions govering reproduction
3.5.4 Data protection requirements
3.5.5 Language of material
3.5.6 Finding aids
3.6 Applied Materials Area
3.6.1 Related units of description
3.6.2 Associated material
3.6.3 Publication produced by the originating body
3.6.4 Publication produced by external researchers
3.7 Original system Attributes Area
3.7.1 Hardware
3.7.2 Operating system
3.7.3 Application software
3.7.4 User interface
3.8 Archive Management Area
3.8.1 Digital processing and arrangement
3.8.2 Content validation
3.8.3 Transformation validation
3.9 Note Area
3.9.1 Note

Figur 1. Shepherd \& Smiths (2000, s. 68) forslag til udvidelse af $I S A D(G)$ 
konkluderer, at der trods mangler er en stor grad af korrelation mellem de metadata, som et ISO 15489certificeret system skulle producere, og de informationskrav som kræves af arkivbeskrivelser ifølge $\operatorname{ISAD}(\mathrm{G})$. Hvis det derfor kan sikres, at disse metadata faktisk bliver produceret, og at de overføres, mens de eksisterer, er Shepherd \& West (2003b, s. 66f) optimistiske med hensyn til at få sikret at e-arkivalier bliver beskrevet tilstrækkeligt.

Forbeholdene i Shepherd \& Wests optimistisk konklusion er imidlertid ikke uvæsentlige. Den første del handler om implementering af e-systemer og procedurer i virksomheden og er en hel forskningsgren for sig (se fx Oliver, 2007 og Højmark Larsen, 2004).

Den anden del knytter an til bevaringsmetadata (preservation metadata) og bevaringsstrategier, der berører den mere tekniske side af langtidsbevaring.

\section{Bevaringsmetadata}

Langtidsbevaring af digitale objekter (og metadata) er et voksende problem. Primært fordi både producenter og forbrugere af elektroniske løsninger har et andet fokus - nemlig den daglige brug. Bevaringen har derfor heller ikke været tænkt ind i vores informationsstruktur fra begyndelsen. Først fra starten af det nye årtusinde er der sat større projekter i gang med at udvikle holdbare bevaringsstrategier. Strategierne forsøger at råde bod på de problemer, der opstår på grund af 1) de elektroniske mediers samt software og hardwares relativ korte levetid og 2) den digitale informations fleksibilitet, der trods sine mange fordele har den ulempe, at det er vanskeligere at stole på autenticiteten (Day, 2004, s. 253f).

Ifølge Day (2004, s. 254f) er der identificeret fire forskellige strategier, henholdsvis: bevaring af teknologien, emulation, migration og indkapsling. På nær den første er strategierne afhængige af indhentning, skabelse og vedligeholdelse af (bevarings-)metadata, der muliggør gendannelse og fortolkning af informationsobjekters indhold og struktur over tid.

- Bevaring af teknologien (også kaldet den museale strategi) er baseret på en opbygning af samlinger af forældet hardware og software, der kan læse data i deres oprindelige miljø.

- Emulation baserer sig på udvikling af software, der kan efterligne det oprindelige miljø på nye platforme.
- Migration er periodiske overførsler af information fra en generation af computerteknologi til den næste.

- Indkapsling bygger på ideen om, at det enkelte informationsobjekt indkapsles sammen med tilstrækkelig af ekstra information til, at det kan dechifreres og forstås på et senere tidspunkt.

Den museale strategi bliver af de fleste vurderet som urealistisk. Det vil kræve for mange resurser, at opbygge og vedligeholde (hvis muligt) en sådan samling af udtjent hardware og software, og tilgængeligheden vil være begrænset. Ifølge Rothenberg (1998) må man derfor bevare det originale på en anden måde. Han argumenterer for emulationstrategien, som den eneste holdbare løsning, da der sker et for stort tab af objekternes kontekst og struktur i konverteringsstrategierne. En analogi for Rothenberg er, hvis Homer skulle have været oversat til moderne engelsk gennem de sidste 2500 års mellemliggende sprog. Problemet med emulering er, at det kræver betydelige resurser at udvikle disse emulatorprogrammer.

Den mest benyttede strategi er migration, primært fordi softwareproducenterne allerede har taget højde for det i deres produktudvikling, eller fordi migration har en kortsigtet relevans for den enkelte virksomhed. Der er imidlertid flere problemer forbundet med strategien: 1) det vil kræve hyppige migreringer, ellers vil konverteringen ikke være mulig; og 2) data og datarelationer vil typisk ændre sig en smule, hvilket kun vil blive værre med tiden. I det lange perspektiv er indkapslingsstrategien derfor vurderet som bedre (se fx ICA, 2005, s. 54). Også her er der tale konvertering, men om konvertering til et så vidt muligt systemuafhængigt standardformat, der skulle kunne læses af fremtidig programmel. I realiteten er der tale om en form for migrering, der opererer med længere intervaller.

Den mest omtalte model for langtidsbevaring af informationsobjekter, der baserer sig på indkapslingsstrategien, er 'The Reference Model for an Open Archival Information System" (OAIS), der er udviklet for at standardisere arkiveringen af rumfartens data. Modellen blev til i samarbejde med ISO og er nu optaget som ISO 14721:2003. Den beskriver helt overordnet strukturen for en såkaldt 'Archival Information Package' (AIP) indeholdende henholdsvis 'content information', 'preservation description 
information', 'package information' og 'descriptive information about package' (se Figur 2).

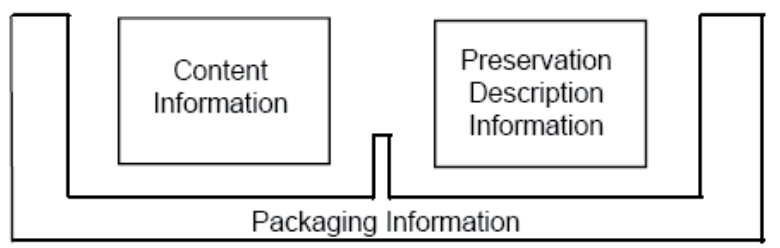

Package 1

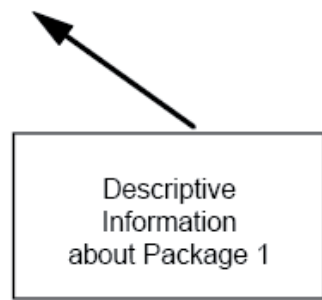

Figur 2. Informationspakkebegreber og -relationer (CCSDS 650.0-B-1, 2002)

Modellen har inspireret arkivverdenen. Senest er OAIS blevet diskuteret på et møde i april 2006 for de statslige arkiver i Norden om tilgængeliggørelse af elektroniske arkivalier, hvor især Statens Arkiv i Sverige kunne berette om deres brug af modellen (bjóðskjalasafn Íslands, u.d.).

Det fremgår dog ikke af Statens Arkiver (SA) i Danmarks egen publikationer, at OAIS skulle have været en inspiration for valg af bevaringsstrategi, men på flere måder minder AIP'en om SA's 'arkiveringsversion'. Strategien bag arkiveringsversionen, er baseret på indkapsling (dog af SA kaldt konvertering eller 'omformning til tidssvarende standarder') og valgt, fordi den vurderes som bedre end migrationsstrategien og som mere økonomisk realistisk end både emulation og den museale strategi. Konkret skal arkivskaberne - de offentlige myndigheder - således producere og aflevere en sådan version af deres e-system til SA, inden der sker sletning af data, eller inden systemerne går ud af administrativt brug. Typisk betyder det en arkivering hvert 5 . år, for at undgå at data går tabt ved sletning (fx som følge af Persondataloven) eller ved teknologisk forældelse. I implementeringen af strategien indgår, at SA godkender myndighedernes nye systemer (Kristmar, 25.1.2007, se også Vejledning til Bekendtgørelse om arkiveringsversioner af bevaringsvaerdige data fra elektroniske arkivsystemer, Marts 2004). De private arkivskabere anbefales at følge samme standard for bevaring af elektroniske arkivalier, som gælder for de offentlige myndigheder (Redegørelse til Privatarkivudvalget, 15.9.2007, s. 16).

Indholdet af SA's arkiveringsversion (se Figur 3) indeholder udover selve informationsobjekterne forskellige former for metadata. Som OAIS' indholdsinformationspakke består arkiveringsversionen af dels data vedr. objektets indhold (semantisk dokumentation), dels objektets struktur (kaldet syntaktisk dokumentation).

Indkapslingsmetaforen passer meget godt på det SA gør, da det afleverede materiale indtil i dag "blot" bevares på et standardiseret, systemuafhængigt format. For først på et senere tidspunkt at udvikle programmer til at tilgængeliggøre det, hvilket jo er formålet med bevaringen ${ }^{4}$. Netop tilgængeliggørelsen er derfor også et af SA's aktuelle satsningsområder. Som et delprojekt under Tilgængeliggørelsesprojektet (TGP12), der har været fastsat til at "undersøge behov og muligheder for kortfattede arkivskabte beskrivelser af e-arkivalier med henblik på at lette identifikationen" (Hansen, Maj 2007, s. 7), har Else Hansen udviklet et spørgeskema (Hansen, Maj 2007, Bilag 4), der skal indhente yderligere informationer om e-systemerne hos de afleverende myndigheder. ${ }^{5}$ Disse beskrivelser (metadata) og dette spørgeskema vil jeg se nærmere på i den næste del af artiklen, hvor jeg undersøger situationen i den danske fagbevægelse.

\section{Spørgeskemaundersøgelsen}

Da SA er den største aktør på feltet i Danmark og derved skaber præcedens, har jeg valgt at ligge min empiriske undersøgelse op af TGP12, og min spørgeskemaundersøgelse tager derfor udgangspunkt i det af Hansen udviklede spørgeskema. Skemaet betegnes som et dokumentationsskema for e-systemer, hvis formål er at give arkivbrugerne en række oplysninger (kaldet General information - se Figur 3), der skal gøre dem istand til dels at finde de relevante arkivalier, dels at vurdere deres kildeværdi. Med henvisning til Gilliland (u.d.) kan man sige, at fokus er på metadata om indhold og kontekst på systemniveau.

Mere specifikt har Hansen (Maj 2007) opstillet en række områder, der vurderes som vigtige at få dokumenteret. Hansen trækker især på et forstudie af Smith Jespersen (Januar 2005), der har set på 'best 


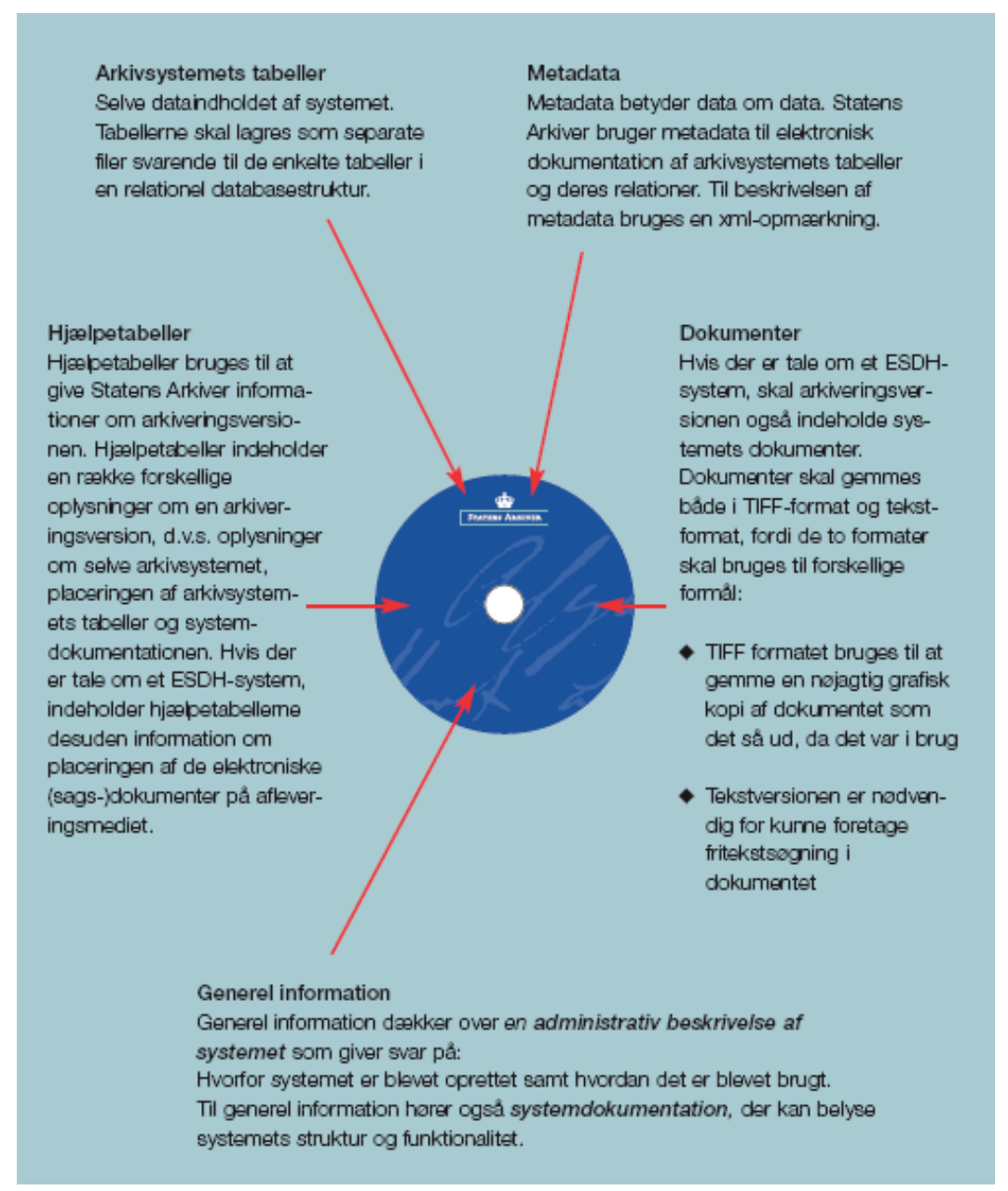

Figur 3. SA's arkiveringsversion (Arkivhåndbogen for statslige myndigheder, 2005, s. 67)

practice'-projekter i ind- og udland, bl.a. OAIS og ISAD $(\mathrm{G})$. Ligesom det bygger videre på SA's tidligere praksis vedr. e-arkivalier ${ }^{6}$ og på dansk arkivteori, der også har ligget i SA's regi. Det anbefales at dokumentere følgende områder:

- "E-systemets formål og indhold

- Overførsel af data til og fra andre e-systemer

- E-systemets administrative funktioner, herunder retningslinjer for indtastning i e-systemet

- Lovmateriale som baggrund for e-systemets oprettelse og brug

- E-systemets fælles funktioner med ældre og nyere systemer

- Myndighedernes egen kvalitetskontrol

- E-systemets tekniske udformning" (Hansen, Maj 2007, s. 8)
SA's dokumentationsskema er rettet mod afleverende, statslige myndigheder. Dette er ikke tilfældet i min undersøgelse. For det første er de arkivskabere, der afleverer arkiver til ABA, ikke offentlige. De er private og er derfor hverken underlagt Arkivloven eller Offentlighedsloven, hvilket betyder, at hver enkelt organisation selv bestemmer, hvordan og hvor meget, der skal arkiveres. E-systemerne er heller ikke anmeldt og godkendt af ABA, ligesom de ikke er udviklet i samarbejde med ABA. For det andet er målgruppen ikke i en afleveringssituation. Der er derfor tale om systemer, der stadig er i brug. Som konsekvens af dette har det været nødvendigt at tilpasse skemaet.

Derudover blev der tilført yderligere spørgsmål om deltagerne; om hvilke metadata, der tilføres sagerne/ dokumenterne; og om forbundets stilling til lang- 
tidsbevaring - de sidste to typer af spørgsmål for at inddrage henholdsvis de lavere aggregeringsniveauer og metadata om dokumentstrukturen i systemerne samt bevaringsaspektet (se skemaet sidst i artiklen). Da der imidlertid ikke blev svaret fyldestgørende på spørgsmålet omkring metadata på sags- og dokumentniveau, har dette aspekt af problemstillingen ikke været mulig at forfølge nærmere. Andre mangelfulde besvarelser er forsøgt suppleret med oplysninger fra e-system-producenternes hjemmesider. Samtidig har undersøgelsen givet en række resultater, der har haft mindre relevans for artiklens problemstillinger, og som derfor er udeladt her.

\section{Deltagerne}

I alt 8 ud af 17 forbund svarede på spørgsmål i spørgeskemaet. Tilsammen dækker de deltagene forbund $84 \%$ af forbundenes i alt ca. 1.348 .850 medlemmer (LO, u.d.). Så selvom kun omkring halvdelen af forbundene svarede, repræsenterer deltagerne hovedparten af de LO-organiserede lønmodtagere. På plussiden er især, at de tre store forbund valgte at deltage: FOA - Fag og Arbejde (FOA), HK/Danmark (HK) og NN1 ${ }^{7}$. Samtidig fik jeg også svar fra både mellemstore (under 100.000 medlemmer): Teknisk Landsforbund (TL), Dansk El-Forbund (DEF) og NN2; og mindre (under 30.000) forbund: Blik og Rørarbejderforbundet (Blik og Rør) og Malerforbundet i Danmark (MFD). Jeg vil senere bruge denne opdeling af forbundene i mindre, mellemstore og store til at generalisere om tilstanden på e-arkivområdet i fagbevægelsen.

\section{Forbundets primære e-systems navn}

Af de 8 deltagende forbund oplyste to forbund, at de ikke har et e-system. Det drejer sig om Blik og Rør og MFD, der også er de to mindste forbund i undersøgelsen. På den baggrund kunne det antages, at de endnu mindre forbund, der har valgt ikke at deltage, heller ikke har et e-system.

De resterende nævner følgende navne på deres e-systemer:

- TL og NN2: Winnie

- DEF: Modulus

- FOA: Acadre Case Management

- HK: EDH

- NN1: Aurora
Winnie og Modulus leveres som standardprodukter af henholdsvis Organisator, der er en del af KMD, og det finsk-svenske TietoEnator. Ifølge TietoEnator (17.7.2007) skulle Modulus yderligere benyttes af FOA, HK og MFD. For HK og MFD's vedkommende er det i hvert fald gældende fra 2008 (jf. nedenstående afsnit om 'Andre systemer'), mens FOA muligvis har Modulus som et sekundært system. FOA's Acadre udbydes af Traen. Derudover indgik Forbundet Træ-Industri-Byg i Danmark (TIB) i 2006 en aftale med TietoEnator om implementering af Modulus (Nilsson, 27.9.2006). Winnie-systemet bliver også brugt af Dansk Funktionærforbund - Serviceforbundet (DFF-S) (Organisator, u.d.a). Endelig formidler Organisator Scan•Jour-produktet Captia, som Dansk Metalarbejderforbund (Metal) og Socialpædagogerne (SL) benytter sig af (Scan•Jour, u.d.; Organisator, 29.1.2007). Hvis man ser bort fra de store forbund, NN1 og HK, er der altså en klar tendens til at vælge standardsystemer.

\section{Dato for e-systemets ibrugtagen}

Yderår er en af de mest gængse informationer, hvoraf relevans af materiale kan vurderes. Til dette spørgsmål har jeg fået følgende besvarelser:

- NN2: 4.12.2006

- FOA: August 2004 - ultimo juni 2006

- HK: ultimo 2002

- NN1: 2000

FOA implementerede systemet $\mathrm{i}$ etaper. I august 2004 kom de første brugere på. En egentlig "udrulning” startede i november 2004, og først i juni 2006 var alle de tiltænkte brugere koblet på. NN1 og HK's systemer er de ældste, hvilket kunne være grunden til, at de ikke anvender standardprodukter. For bare 5-7 år siden var markedet for e-systemer betydeligt mindre og i højere grad præget af individuelle og mindre omfattende løsninger. ESDH-systemer var et særsyn i Danmark før 2000. Ifølge Hall-Andersen (2000, s. 68) havde SA i 2000 kun modtaget 30 ESDH-anmeldelser fra de offentlige myndigheder.

\section{Udvikling og drift af e-systemet}

Spørgsmål og besvarelse delte sig i henholdsvis udvikling og drift: 
Udvikling:

- NN2: Organisator

- FOA: Traen Informationssystemer A/S og FOA's ESDH-Projektgruppe

- HK: HK i samarbejde med IBM

- NN1: NN1

Organisator står bag udviklingen af medlems- og a-kassesystemet Winnie. De deltagende forbund og a-kasser indgår i dag i et ledelsesforum, der følger udviklingen af nye versioner af Winnie. Et af målene for udviklingen af systemet er, at harmonisere forskellige varianter af Winnie-systemet (Østerfelt, 12.6.2006). De større forbund har deltaget mere aktivt i udviklingen af deres systemer. NN1 har således ifølge besvarelsen selv udviklet systemet.

Dette sidste lader ikke til at være en fordel i forhold til dokumentation i form af kravspecifikation og af systemets tekniske udformning, der ifølge NN1's besvarelse ikke eksisterer for Auroras vedkommende. Modsat NN2, FOA og HK, der alle skulle ligge inde med dokumentation for de to områder. DEF har ikke besvaret spørgsmålet, men Modulus er som sagt udviklet af TietoEnator. Der er endvidere markeret, at DEF ikke skulle være i besiddelse af dokumentation vedr. udviklingen af systemet. Som jeg har været inde på, kan denne dokumentation være afgørende for en fornuftig langtidsbevaring af indholdet i systemet. Det kan ikke forudsættes, at den manglende information efterfølgende kan indhentes hos producenten. På grund af konkurrencehensyn er producenterne generelt ikke åbne omkring det specifikke indhold af systemerne.

Drift:

- NN2: Organisator

- FOA: Pen-Sam (1.8.-31.12.04), TietoEnator (1.1.05-31.8.07) og FOA (1.9.07-)

- HK: KMD

- NN1: NN1

Driften varetages både internt og eksternt. Igen står NN1 selv for det, mens de øvrige tre forbund samarbejder med eksterne partnere. NN2, FOA og HK har angivet, at der eksisterer dokumentation for forhold vedr. e-systemets drift. NN1 har ikke besvaret spørgsmålet. FOA's besvarelse antyder, at forhold omkring driften kan have ændret sig, da det har været nødvendigt skifte driftaktør flere gange inden for relativ kort tid. Sådanne hyppige skift vil foranledige behov for ekstra opmærksomhed på sikring af dokumentation af evt. ændringer i relation til systemet og dets indhold.

Ifølge Organisator (u.d.b) samarbejder firmaet med 10 ud af 17 LO-fagforbund: DEF, Dansk Frisør og Kosmetiker Forbund, DFF-S, Metal, FOA, HK, NN2, SL, TL og TIB. Omfanget og perioden for de enkelte samarbejder fremgår ikke. Det er samtidig tydeligt, at der mellem TietoEnator og Organisator kappes om at have den største del af fagbevægelsen som kunder. TietoEnator (5.4.2006): "Ser vi på markedet i dag er TietoEnator den førende leverandør til fagforbund og a-kasser: Vi er nr. 1 målt på medlemstal. Vi er nr. 1 målt på antal kunder." Begge påstande kan være rigtige, da AC-, FTF- og "gule" fagforeninger også indgår i kundegrundlaget. Derudover driftede Organisator i 2004 konkurrentens system, Modulus, for to forbund (Organisator, 2004).

\section{E-systemets formål og indhold}

De to mellemstore forbund svarer således på spørgsmålet om e-systemets formål og indhold:

- DEF: "Der anvendes stadig papirarkiv/-sager i Formandssekretariatet. Fagligt sekretariat gemmer elektroniske og skannede dokumenter i Windows fil-systemets mapper. Faglige sager tildeles entydigt journalnummer, der udtrækkes /reserveres i hjemmelavet system. Man kan søge på tekster i to beskrivelsesfelter: Titel og Vedrører."

- NN2: "Winnie-systemet varetager alle de vigtigste administrative funktioner omkring driften og administrationen af [NN2]'s a-kasse. Systemet indeholder også faciliteter, så vi har styr på og kan administrere vores faglige forhold. Dette rækker væsentlig længere end blot at registrere navn og adresser på tillidsfolk."

DEF og NN2 har begge primært et medlems- og akassesystem, henholdsvis Modulus og Winnie. De har angiveligt de samme behov for elektronisk dokumentstyring, men har valgt lidt forskellige veje til at afhjælpe deres behov. De har begge udvidet deres elektroniske organisering med henblik på faglige sager, men mens DEF ved hjælp af almindelige filserverfunktioner selv har udviklet et søgesystem, har NN2 købt ekstra funktioner i Winnie. Undersøgelsen siger ikke noget om, hvordan de forskellige løsninger 
virker, men med hensyn til dokumentation, så skulle den være tilstede for NN2's vedkommende.

FOA, HK og NN1 har alle EDH/elektronisk sagsog dokumenthåndteringssystemer (ESDH) og giver derfor andre svar på spørgsmålet. Svarene er præget af større ambitioner end at løse praktiske problemer. Det er gennemgående, at forbundene ønsker at udnytte systemernes vidensdelende egenskaber i deres sagsbehandling til gavn for deres medlemmer. De vil kort sagt gerne give en bedre service. Det lader til at være det primære mål. Derudover kan der nok heller ikke være tvivl om, at der også ligger et stærkt ønske om rationalisering bag implementeringen af systemerne. Især i besvarelsen fra FOA er dette element fremtrædende. Som sidegevinster nævnes bedre forhold for de ansatte i forbundene og større gennemsigtighed i sagsbehandlingen igen til gavn for medlemmerne.

Fra et arkivperspektiv er det interessant, at HK forestiller sig, at den elektroniske dokumentstyring vil mindske resurseforbruget til arkivering, samt at ingen forbund nævner noget om langtidsbevaring eller historiske perspektiver. Det er imidlertid ikke overraskende eller uforståeligt, da fokus er, som jeg allerede tidligere har nævnt, på den daglige virksomhed. Det antyder imidlertid, at der kan opstå udfordringer i forhold til betaling for langtidsbevaring, der formentlig hurtigt kan komme til at neutralisere tidligere opnåede rationaliseringsgevinster.

Disse overordnede mål/motivationer for indførelsen af systemerne siger dog ikke meget om selve systemet og dets indhold og har derfor begrænset værdi for fremtidige arkivbrugere. De forventede svar i SA's dokumentationsskema (Hansen, 2007, s. 43) peger også mere i retning af de yderligere oplysninger, som FOA og HK har givet om systemernes interne afgrænsninger i organisationerne:

- FOA: "I forhold til udbredelsen er det sådan, at al medlemsrelateret sagsbehandling i a-kassen og mellem forbund og afdelinger foregår via Acadre. Øvrige sager afhænger af, hvor sagen er placeret: A-kassen - her foregår al sagsbehandling via Acadre. Forbundshuset - her foregår det meste sagsbehandling via Acadre. Lokalafdelingerne - her er det meget forskelligt, i hvilket omfang der sagsbehandles via Acadre eller på almindelige fil-drev."
- HK: "Hvem skal benytte EDH: EDH retter sig i første omgang mod sagsbehandlere indenfor akassen og medlem/kontingent, men på længere sigt forventes EDH tillige implementeret i den faglige gren til afløsning for JASS.”

Ligesom for DEF og NN2 er det primært a-kasserne, der er dækket af systemet. Derudover er al medlemsrelaterede sager tilsyneladende dækket af systemet. Det er uvist, om HK har udvidet systemet til "den faglige gren" siden indførelsen af systemet. Dette er oplysninger, der har afgørende betydning for en vurdering af systemets kildeværdi.

Endelig har HK givet en beskrivelse af deres systems nærmere indhold:

"EDH er HK's løsning til elektronisk arkivering af dokumenter. De dokumenter som arkiveres elektronisk kan være:

- Breve som HK modtager enten i form af breve eller andre dokumenter på papir.

- E-mails med tekst eller e-mails med både tekst og medsendte filer.

- Breve som HK sender til medlemmer."

Dette må dække den primære elektroniske kommunikation, der finder sted i alle virksomheder. Derudover må man formode, at der også eksisterer elektroniske medlemsregistre o.lign., der består af skemaindtastet data. Dette oplyses der ikke noget om, men det er klart at registre også vil indeholde unik information, der i fremtiden vil kunne udnyttes af fx slægtsforskere og til statistiske studier.

Med hensyn til dokumentation for e-systemets formål og indhold gør det sig igen gældende, at NN2, FOA og HK skulle være i besiddelse af dokumentation, mens NN1 ikke har en sådan. Det kunne derfor tyde på, at der er dokumentations- og bevaringsmæssige fordele ved standardiserede løsninger og/eller systemer, der er udviklet i samarbejde med etablerede firmaer i branchen.

Kun FOA har angivet, at deres metadatasæt lever op til nationale eller internationale standarder, nemlig Noark-4 og FESD. Noark-4 er betegnelsen for den 4. udgave (1999) af standarden Norsk Arkivsystem, der er en kravspecifikation for elektroniske arkivsystemer (e-systemer) i den offfentlige forvaltning i Norge - en såkaldt applikationsstandard. Standar- 
den gælder altså for hele systemer/produkter, der skal certificeres inden de kan sælges til offentlige myndigheder. Standarden relaterer sig derfor ikke kun til dokumenter, men dækker fire hovedområder: informationsindhold, datastruktur, funktionalitet og brugergrænseflade (Nielsen, 1999, s. 42f).

Noark-4 er sammen med MoReq grundlaget for udviklingen af FESD-standarderne, der som tidligere nævnt, er udviklet til de offentlige myndigheder i Danmark. I praksis er de imidlertid i lige så høj grad udviklet til potentielle leverandører af ESDH'er, der skal leve op til standarderne for at komme i betragtning. På baggrund af FESD blev der i 2004 udvalgt tre konsortier med hver deres system, som de statslige og kommunale institutioner kan entrere med. De tre systemer er Acadre fra Traen, Captia fra Scan•Jour og Public $360^{\circ}$ fra Software Innovation (Steinmark, 2005, s. 372). Med udgangen af 2008 skal Økonomistyrelsens FESD-enhed have udarbejdet en kravspecifikation til FESD II, der efterfølgende vil komme i udbud (Nyt udbud af FESD II, 13.3.2008).

På linje med de internationale bestræbelser med ISO 23081 vurderes disse FESD-systemer, ifølge Steinmark (2005, s. 369f), også til at være en forudsætning for en tilfredsstillende langtidsbevaring:

"From an archival point of view, the FESD project is an invaluable chance to ensure that, when the results of the full digital administration penetrate the whole of the public sector, the effect will not solely be simpler work routines and better services to the public, but also that documentation practices and legislative demands are met, made easier and the whole life cycle for electronic archives from birth through to archiving and preservation is simplified."

Udfra et langtidsbevaringsperspektiv må den bedste løsning derfor også for LO-fagforbundene være et FESD-certificeret system.

\section{Andre systemer}

Dokumentation af hvilke e-systemer, der afløser hinanden og på hvilken måde, er afgørende for at vurdere indholdet af systemerne. Er dokumenter fra et tidligere system $\mathrm{fx}$ konverteret til det næste? DEF, HK og FOA har svaret, at deres system ikke tidligere afløste et andet. Undersøgelsens resultater viste, at følgende tidligere systemer har været i brug:

- TL: TLMAK 2000

- NN2: ARKE

- FOA: CUBUS

TLMAK blev udviklet af TL selv. Der er ikke givet tidspunkter for systemet. Perioden for NN2's ARKEsystem angives til at være 1977-2006, hvilket må siges at være en overraskende tidlig start. FOA angiver systemet CUBUS, uden periodeangivelse og uden nærmere beskrivelse af systemet. Både TL, NN2 og FOA har konverteret data fra de tidligere systemer til deres nuværende.

Til spørgsmålet om fremtidige systemer angiver Blik og Rør, at de går over til "Gammel" Modulus i februar/marts 2008. Hvad "Gammel" dækker over er uklart, men det kunne være a-kasse-modulet. DEF udvider deres Modulus i 2009, hvor der udover medlems- og a-kasse-funktionerne skal integreres et sagsmodul i systemet. Samme system overgår HK til i 2008. TL, NN2, FOA og NN1 har ifølge besvarelsen ikke planer om at overgå til et nyt system inden for en kendt fremtid.

Besvarelserne giver samlet set et indtryk af, at der i de seneste år er udskiftet mange primære systemer. De gamle systemer, der havde sin hovedvægt på medlems- og a-kassestyring opgraderes til mere udviklede ESDH'er, der kan håndtere større dele af forbundenes elektroniske kommunikation og arkivdannelse.

\section{Langtidsbevaring}

Til sidst blev der spurgt til, om forbundene har taget stilling til langtidsbevaring af deres nuværende esystem. Det var der ingen, der havde, og kun NN2 havde langtidsbevaret et tidligere system (på DVD). I spørgeskemaet bliver der ikke opstillet en definition på langtidsbevaring. Det er, som antydet her i artiklen, heller ikke en entydig størrelse, men hvis man med langtidsbevaring mener, som SA gør, at arkivskaberen afleverer en systemuafhængig arkivversion af e-systemet til en arkivinstitution, så er NN2's langtidsbevaring ikke tilstrækkelig. Det skal dog indskydes, at ifølge 'records continuum'-tænkningen vil selve placeringen af materialet $i$ en arkivinstitution ikke være afgørende, men alt andet lige vil der være 
flere fordele ved at benytte allerede eksisterende strukturer for arkivhåndtering.

Den bedste forklaring på, at forbundene ikke har taget stilling til langtidsbevaring af deres systemer, må være, at de dels har et andet fokus i deres daglige arbejde, dels at de i praksis forfølger en anden bevaringsstrategi, nemlig migrationsstrategien. Ud fra besvarelserne tyder det på, at de sætter deres lid til, at de dokumenter, der arkiveres i deres systemer, og disse dokumenters tilknyttede metadata, kan konverteres til nye systemer, så længe dokumenterne er relevante for virksomheden. Endvidere skal det økonomiske aspekt af en langtidsbevaring ikke undervurderes. Som jeg har været inde på, kan det blive en betydelig udfordring at få de private arkivskabere til at betale for langtidsbevaringen, hvis digitaliseringen af virksomhedens dokumentstyring i udgangspunktet var tænkt som en spareøvelse i forhold til arkivering.

Konsekvensen af migrationsstrategien vil være, som jeg også har været inde på, at der sker uhensigtsmæssige dataændringer, der kan skabe usikkerhed om dokumenternes autenticitet og derved skade deres kildeværdi samt i værste fald gøre materiale utilgængeligt.

\section{Perspektivering af resultaterne}

Min undersøgelse har givet nogle pejlemærker for, hvad der kan være af udfordringer med langtidsbevaring af de danske LO-fagforbunds e-arkiver. Af resultatet tegner der sig et billede af, at 1) de mindre forbund endnu ikke benytter sig af e-systemer, at 2) de mellemstore forbund har udvidede e-registre i form af medlems- og a-kassesystemer; og at 3) de store forbund har EDH eller ESDH.

Potentielt set må det derfor forventes, at det største problem ligger hos de mindre forbund. Her må det formodes, at e-dokumenter ligger spredt rundt på forskellige filservere, hvilket der nok aldrig vil blive sat resurser af til at reorganisere. I de tilfælde må man håbe, at der som for DEF's formandssekretariats vedkommende eksisterer papirarkiver, ellers er risikoen for at organisationernes historie forsvinder stor. Om der arkiveres dokumenter i papirform er ikke blevet undersøgt i denne undersøgelse.

De mellemstore forbund har ifølge mine resultater indtil nu primært haft e-systemer til at varetage deres medlems- og a-kasse-funktioner. Derudover har de udvidet området til at dække faglige sager. Der er tilsyneladende gjort brug af forskellige løsninger, der har forskellige konsekvenser. Samlet set er der dog en orientering mod standardløsninger, hvilket må vurderes som positivt i forhold til at opfylde krav om tilstrækkelige tilknyttede metadata. Der er tilsyneladende også en bevægelse mod mere omfangsrige systemer, hvilket SL's Captia er et eksempel på. For de mellemstore forbund er udsigterne derfor bedre, men set i forhold til at medlems- og a-kassemateriale normalt ikke indeholder samme historiske værdi, som det mere politiske materiale fra de beslutningsdygtige organer i forbundene, er de samme problemer stadig tilstede, som for de mindre forbund.

De store forbund er gået over til elektronisk dokumenthåndtering i form af enten EDH eller ESDH. Her er det positivt, at Metal og FOA benytter sig af FESD-certificerede systemer (henholdsvis Captia og Acadre), der giver den størst mulige sikkerhed for langtidsholdbare løsninger. Resultaterne har ikke givet mulighed for at gå i detaljen med, hvilke metadata, der er findes eller ikke findes i systemerne. I stedet har der været fokus på, om der eksisterer metadata i form af dokumentation for forskellige aspekter ved systemerne, hvilket generelt set har været tilfældet for standardsystemerne. Potentielt set burde der derfor være gode muligheder for at bevare de store forbunds e-arkiver for eftertiden. På den negative side er, at forbundene i praksis arbejder med en anden bevaringsstrategi end den, der anbefales på området. Endnu har kun ét forbund afleveret en arkiveringsversion af et tidligere system til ABA. De andre har konverteret gamle data til de nye systemer, hvilket på længere sigt vil få en negativ betydning for autenticitet og tilgængelighed.

De skitserede problemer skal holdes op mod, hvad der hidtil har været situationen med papirarkiver. For det har jo heller ikke været problemfrit. Til forskel fra offentlige institutioner er vores arkivskabere, som nævnt, ikke underlagt Arkivloven. Det betyder, at ABA langt fra har modtaget al den dokumentproduktion, der har været i den danske arbejderbevægelse. De relevante organisationer og privatpersoner har gennem tiderne gemt og senere afleveret det, de mente kunne have en værdi for dem selv og deres omgivelser på længere sigt. Det har derfor varieret meget, hvad der er gemt af papirarkivalier og følgende er meget gået tabt under vejs. Det er der ikke no- 
get odiøst i. Ingen har haft resurser til at gemme alle papirarkivalier. SA har meget illustrativt et mål om at kassere $85 \%$ af den offentlige papirarkivdannelse (Sode-Pedersen, 2006, s. 14) - hermed selvfølgelig ikke sagt, at det er underordnet, hvem der foretager kassationen.

Det er derfor ikke nødvendigvis nogen katastrofe, at et af forbundenes a-kasse-systemer går tabt, men hvis det viser sig, at der er opstået et decideret hul i den historiske kildemasse, eller hvis centralt politisk materiale er gået tabt, så er det et problem. Målet må derfor være at løse problemerne inden de bliver irreversible. Til det er viden om de teoretiske problemstillinger og den faktiske situation en forudsætning. Derudover består udfordringen for arkivinstitutioner som ABA i at overbevise organisationerne om, at det er til deres eget bedste at følge vore anbefalinger - både på kort og langt sigt. På nuværende tidspunkt må den bedste anbefaling være: køb et standardsystem (gerne FESD-certificeret) og aflever løbende arkiveringsversioner til en arkivinstitution (gerne ABA!).

\section{Konklusion}

Lever forbundene op til standarderne på området? Delvist. For det første er det tilsyneladende kun en mindre del af forbundene, der har implementeret elektronisk sags- og dokumenthåndteringssystemer. De forbund, der ikke har, lever naturligvis ikke op til standarderne. De øvrige gør det tilsyneladende også kun delvist. Som jeg har været inde på er metadatastandarden ISO 23081 og ISO 15489 dominerende internationalt. De opstiller en lang række krav, der skal indfries, hvis virksomheder vil sikre kvaliteten i deres dokumentstyring. LO-fagforbundene refererer ikke selv til ISO-standarderne. De standarder, der refereres til, er derimod den danske FESD-standard, der baserer sig på Noark-4 og MoReq. I min undersøgelse er det FOA og deres FESD-certificerede Acadre-system fra Traen, der skiller sig positivt ud. Derudover er der indhentet oplysninger om, at Metal og SL bruger det FESD-certificerede system Captia fra Scan•Jour. Det tyder derfor på, at der er tre forbund, der lever op til standarderne. De øvrige store forbund har ikke valgt standardløsninger, hvilket bl.a. for NN1's vedkommende giver sig udtryk i manglende dokumentation for forskellige forhold omkring dokumentstyringen.
For arkivinstitutionerne er det afgørende, om der kan forventes at være tilstrækkelig metadata til at sikre en tilfredsstillende langtidsbevaring af forbundenes fremtidige e-arkivalier. Dette er relateret til om forbundene lever op til standarderne for dokumentstyringsmetadata. Hvis det kan sikres, at standardernes krav til metadataproduktionen bliver fulgt, og at metadata og dokumenter indhentes, mens de eksisterer, så vil der være en god mulighed for at e-arkivalierne kan beskrives i arkivinstitutionernes systemer i et tilstrækkeligt omfang (jf. Shepherd \& West, 2003b). Det sidste skal sikres ved, at den rigtige bevaringsstrategi følges.

Her står vi overfor en stor udfordring, da $\mathrm{ABA}$ indtil nu kun har modtaget et enkelt e-arkiv. I stedet for at aflevere arkiveringsversioner af deres systemer har forbundene valgt at konvertere gamle dokumenter til deres nye systemer, hvorved de forfølger migrationsstrategien, der ikke anbefales på området. Konsekvensen ved ikke at aflevere systemuafhængige arkiveringsversioner, som fx Statens Arkiver anbefaler, og som følger af indkapslingsstrategien, er, at der vil ske ændringer i data og datarelationer, der med tiden vil forurette skade på dokumenternes autenticitet og tilgængeligheden til dem. Ligeledes vil sandsynligheden for, at tilstrækkeligt metadata i form af dokumentation for forskellige aspekter ved tidligere systemer bliver bevaret, være begrænset.

\section{Noter}

1. Artiklen baserer sig på min masterafhandling fra Danmarks Biblioteksskole (Jørgensen, Oktober 2007).

2. Dokumentstyring' er Dansk Standards oversættelse af 'records management'. Oversættelsen responderer ikke med oversættelsen af 'electronic records management systems', der som bekendt betegnes som 'sag- og dokumenthåndteringssystemer' på dansk. 'Dokumentstyring' og 'sagsog dokumenthåndtering' vil på den baggrund blive behandlet som synonymer her i opgaven. Det samme gælder for 'records management' og 'recordkeeping', hvor det første begreb de senere år har afløst det sidste.

3. Datasæt defineres som en samling af rå data, der er fjernet fra deres oprindelige computermiljø (databaser) (Shepherd \& Smith, 2000, s. 57). 
4. Statens Arkiver har i oktober 2008 lanceret softwareprogrammet Sofia (Søg og find i arkiveringsversioner).

5. Skemaet indgår i et pilotprojekt (2007-2008), der foreslås fulgt op af et kravsrevisionsprojekt, og kan derfor ikke opfattes som et endeligt udviklet skema (Hansen, Maj 2007, s. 61 og Bilag 6 (projektbeskrivelse)).

6. Se fx SA's Anmeldelsesskema (2002) og HallAndersens (2000) gennemgang af resultaterne fra en spørgeskemaundersøgelse foretaget af SA i 2000 .

7. To forbund ønskede anonymitet ved en evt. offentliggørelse af resultaterne. De vil derfor figurere som NN1 og NN2.

\section{Referencer}

Anmeldelsesskema. Anmeldelsesskema til elektroniske journalsystemer samt elektroniske dokumenthåndteringssystemer (EDH og ESDH-systemer) (2002). Statens Arkiver. Lokaliseret 20.5.2008 på WWW: http://oldwww.sa.dk/statslige_myndigheder/ stat/vejl/anmskema.pdf.

Arkivhåndbogen for statslige myndigheder. Fra informationer til arkivalier (2005). Statens Arkiver. Lokaliseret 20.5.2008 på WWW: http://oldwww. sa.dk/statslige_myndigheder/stat/vejl/ah_samlet.pdf.

CCSDS 650.0-B-1 (2002). Reference Model for an Open Archival Information System (OAIS). Washington, D.C.: Consultative Committee on Space Data Systems. Lokaliseret 20.5.2008 på WWW: http://public.ccsds.org/publications/archive/650x0b1. pdf.

Day, M (2004). Preservation metadata. I: G.E. Gorman, \& D.G. Dorner (Eds.). Metadata. Applications and Management. International Yearbook of Library and Information Management 2003/2004 (s. 253273). London: Facet Publishing.

Gilliland, AJ (u.d.). Setting the Stage. I: M. Baca (ed.), Introduction to Metadata. Pathways to Digital Information. Online Edition, Version 2.1. Lokaliseret 20.5.2008 på WWW: http://www.getty.edu/research/ conducting_research/standards/intrometadata/setting. html.

Gilliland-Swetland, A (2005). Electronic Records Management. Annual Review of Information Science and Technology (ARIST), 39, 219 - 253.

Hall-Andersen, M (2000). De statslige myndigheders brug af IT - en spørgeskemaundersøgelse. Fuld elektronisk arkivering i staten er stadig fremtidsmusik. ARKIV, 5, 67 - 71 .

Hansen, B (1999). IT-udviklingen i Statens Arkiver. Opgaver og strategier for Statens Arkivers IT-afdeling. ARKIV, 4, 23 - 30.

Hansen, E (Maj 2007). Arkivskabte beskrivelser og administrationshistorisk dokumentation af e-arkivalier. Tilgængeliggørelsesprojektet, delprojekt 12. Rigsarkivet. Lokaliseret 20.5.2008 på WWW: http:// oldwww.sa.dk/forskning_og_udvikling/itogarkiv/rk/ tgp/tgp12.htm.

Højmark Larsen, V (2004). Hvad har organisationskultur og ESDH med hinanden at gøre? Biblioteksarbejde, 69, 7 - 17 .

ICA (2000). ISAD(G): General International Standard Archival Description. 2. Ed. Ottawa: International Council of Archives. Lokaliseret 20.5.2008 på WWW: http://www.ica.org/sites/default/files/isad_ g_2e.pdf.

ICA (2005). Electronic Records: A Workbook for Archivist. International Council of Archives. Lokaliseret 20.5.2008 på WWW: http://www.ica.org/sites/default/files/Study16ENG_5_2.pdf.

ISO (2006). ISO 23081-1. Information and documentation - Records management processes - Metadata for records - Part 1: Principles. First edition 2006-01-15. International Organization for Standardization. Lokaliseret 22.9.2007 på WWW: https:// committees.standards.org.au/COMMITTEES/IT021/N0001/ISO_23081-1_2006.pdf.

ISO (2007). ISO 23081-2. Information and documentation - Records management processes - Metadata for records - Part 2: Conceptual and implementation issues. STD Version 2.2. Lokaliseret 20.5.2008 på WWW: https://committees.standards.org.au/COM- 
MITTEES/IT-021/N0002/ISO\%2023081-2-200X. pdf.

Jørgensen, J (Oktober 2007). Metadata, langtidsbevaring af e-arkivalier og en undersøgelse af LOfagforbundenes elektroniske informationssystemer. Upubliceret masterafhandling. Danmarks Biblioteksskole.

Kristmar, KV (25.1.2007). Statens Arkivers strategi for modtagelse, bevaring og tilgængeliggørelse af elektroniske arkivalier. Lokaliseret 20.5.2008 på WWW: http://oldwww.sa.dk/forskning_og_udvikling/itogarkiv/strategi/bevaringsstrategi.pdf.

LO (u.d.). Forbund. Landsorganisationen i Danmark. Lokaliseret 20.5.2008 på WWW: http://www.lo.dk/ RUNDTOMLO/LOsmedlemmer/Forbund.aspx.

MacNeil, H (1996). Metadata Strategies and Archival Description: Comparing Apples to Oranges. Archivaria, 39, 22 - 32.

Marker, N, Nymand, U, \& Pedersen, I (2001). Ny ISO standard om dokumentstyring. Er den interessant for bibliotekarer? Bibliotekspressen, 16, 462 $-463$.

Morelli, J (2007). Hybrid filing schemes: the use of metadata signposts in functional file plans. Records Management Journal, 17 (1), 17 - 31.

MoReq2 Scoping Rapport, Version 3 (Februar 2006). DLM-Forum. Lokaliseret 20.5.2008 på WWW: http://dlmforum.typepad.com/MoReq220Scoping20Report.pdf.

Nielsen, AB (1999). NOARK - 4. En norsk kravspecifikation for elektroniske arkivsystemer. ARKIV, 4, $42-46$.

Nilsson, J (27.9.2006). Nyt it-system. Forbundet Træ-Industri-Byg. Lokaliseret 20.5.2008 på WWW: http://www.tib.dk/Nyheder\%20og\%20aktuelt/Nyhedsarkiv/Forbund/Modulus.aspx.

Nyt udbud af FESD II (13.3.2008). Modernisering. dk. Lokaliseret 23.5.2008 på WWW: http://modernisering.dk/da/projektside/staerkere_samarbejde/nyt_ udbud_af_fesd.
Oliver, G (2007). Implementing international standards: first, know your organisation. Records $M a-$ nagement Journal, 17 (2), 82 - 93.

Om FESD (12.3.2007). Modernisering.dk. Lokaliseret 23.5.2008 på WWW: http://modernisering.dk/da/ projekter/fesd.

Organisator (2004). Organisationer der rykker. KundeNyt, 3. Lokaliseret 20.5.2008 på WWW: http:// www.organisator.dk/info.asp?rootId=1488450\&info $\mathrm{Id}=1490250$.

Organisator (29.1.2007). Referat fra Gå-hjem-møde om digitalisering. Lokaliseret 20.5.2008 på WWW: $\mathrm{http}: / /$ www.organisator.dk/info.asp?infoid=1552258.

Organisator (u.d.a). Individuel brugergrænseflade i Winnie. Lokaliseret 20.5.2008 på WWW: http:// www.organisator.dk/default.asp?infold=1490234.

Organisator (u.d.b). Referencer. Lokaliseret 20.5.2008 på WWW: http://www.organisator.dk/default.asp?infold=1489937.

Redegørelse til Privatarkivudvalget vedrørende indsamling, bevaring og tilgangeliggørelse af private earkivalier (15.9.2007). Arbejdsgruppen vedr. private e-arkivalier. Lokaliseret 20.5.2008 på WWW: http:// www.sa.dk/media(1038,1030)/Redeg\%C3\%B8relse vedr $\% \mathrm{C} 3 \% \mathrm{~B} 8$ rende_private_e-arkivalier_september_2007.pdf

Pember, M (2006). Sorting out the standards: what every records and information professional should know. Records Management Journal, 16 (1), 21 - 33.

Rothenberg, J (1998). Avoiding Technological Quicksand. Finding a Viable Technical Foundation for Digital Preservation. Council on Library and Information Resources. Lokaliseret 20.5.2008 på WWW: http://www.clir.org/pubs/reports/rothenberg/ contents.html.

Scan•Jour (u.d.). Dansk Metal. Lokaliseret 20.5.2008 på WWW: http://scanjour.dk/index. aspx?id=f0d967de-6a23-4c8d-aeb5-7aef7871a690.

Schellenberg, TR (1956). The Appraisal of Modern Public Records. Bulletins of The National Archives, 8, 233 - 278. 
Shepherd, E \& Smith, C (2000). The Application of ISAD $(G)$ to the Description af Archival Datasets. Journal of the Society of Archivists, 21 (1), 55 - 69.

Shepherd, E \& West, V (2003a). Are ISO 154891:2001 and ISAG(G) compatible? Part 1. Records Management Journal, 13 (1), 9 - 23.

Shepherd, E \& West, V (2003b). Are ISO 154891:2001 and ISAG(G) compatible? Part 2. Records Management Journal, 13 (2), 62 - 69.

Smith Jespersen, L (Januar 2005). En informationsvidenskabelig og arkivteoretisk undersøgelse af arkivalier og forslag til dokumentation af data $i$ systemuafhcengige arkiveringsversioner af elektroniske arkivalier. UMTS-projekt. Digitalisering af dokumentation af IT-arkivalier. Statens Arkiver. Lokaliseret 20.5.2008 på WWW: http://oldwww.sa.dk/ forskning_og_udvikling/itogarkiv/teknologi/erfa/ edokrapport.pdf.

Sode-Pedersen, A (2006). Tekstreduktion og historiesyn. Et forsøg på dekonstruktion af den danske kassationsdiskurs, s. 11-28. I: E. Bloch \& C. Larsen, At vogte kulturarven eller at slette alle spor. Om arbejdet med den danske bevaringsstrategi. København: Arkivforeningen.

Steinmark, C (2005). EDM in the Danish public sector: the FESD project. Aslib Proceedings, 57 (4), 369 $-377$.

TietoEnator (5.4.2006). A-kasser og fagforbund. Lokaliseret 20.5.2008 på WWW: http://www.tietoenator.dk/default.asp?path=487,616,16089,9672.
TietoEnator (17.7.2007). Modulus referencer. Lokaliseret 20.5.2008 på WWW: http://www.tietoenator. $\mathrm{dk} /$ default.asp?path $=487,616,16089,9672,10267,18$ 703.

Upward, F (1996). Structuring the Records Continuum - Part One: Postcustodial principles and properties. Archives and Manuscripts, 24 (2). Lokaliseret 20.5.2008 på WWW: http://www.sims.monash.edu. $\mathrm{au} / \mathrm{research} / \mathrm{rcrg} /$ publications/recordscontinuum/ fupp1.html.

Upward, F (1997). Structuring the Records Continuum, Part Two: Structuration Theory and Recordkeeping. Archives and Manuscripts, 25 (1). Lokaliseret 20.5.2008 på WWW: http://www.sims.monash. edu.au/research/rcrg/publications/recordscontinuum/ fupp2.html

Wallace, DA (1993). Metadata and the Archival Management of Electronic Records: A Review. Archivaria, 36, 87 - 110 .

Vejledning til Bekendtgørelse om arkiveringsversioner af bevaringsvoerdige data fra elektroniske arkivsystemer. Bekendtgørelse nr. 342 af 11. marts 2004. (Marts 2004). Statens Arkiver. Lokaliseret 20.5.2008 på WWW: http://oldwww.sa.dk/statslige_myndigheder/stat/vejl/aflelek 2004.pdf.

Østerfelt, P (12.6.2006). Winnie Ledelsesforum mødtes for første gang. Wi2Nyt, 2. Lokaliseret 20.5.2008 på WWW: http://www.organisator.dk/default.asp?infoId $=1532149$.

pjóðskjalasafn Íslands (u.d.). Indlæg om OAIS. Lokaliseret 20.5.2008 på WWW: http://www.archives. is/index.php?node $=527$. 


\section{ARBEJDERMUSEET\& ARBEJDERBEVÆEGLSENS BIBLIOTEK OG ARKIV}

\section{Spørgeskema vedr. LO-fagforbundenes e-systemer}

\section{Oversigt over spørgeskemaet}
1. Deltager
2. Forbundets primare e-systems navn(e)
3. Dato for e-systemets ibrugtagen
4. Udvikling og drift af e-systemet
5. E-systemets beslutningsgrundlag
6. E-systemets formål og indhold
7. Tilvejebringelse af e-systemets metadata
8. Andre e-systemer
9. Øvrige oplysninger om e-systemet
10. Publikationer, interne rapporter m.m. af og om data
11. Langtidsbevaring
12. Kontaktperson for evt. yderligere oplysninger

\section{Deltager \\ 1a. Forbund, navn, stilling:}

1b. Ønsker forbundet anonymitet ved evt. videnskabelig offentliggørelse af undersogelsens resultater?

Ja $\square \quad$ Nej $\square$

Navn under 1a. vil under alle omstændigheder blive behandlet konfidentielt.

2. Forbundets primære e-systems navn(e)

2a. E-systemets officielle navn (eventuelle forkortelser opløses):

2b. Almindeligt benyttede kaldenavne (inkl. forkortelser) for e-systemet: 


\section{ARBEJDERMUSEET \& ARBEJDERBEVÆEGELSENS BIBLIOTEK OG ARKIV}

3. Dato for e-systemets ibrugtagen

3a. Dato for ibrugtagning (første inddatering eller overførsel af data):

\section{Udvikling og drift af e-systemet}

4a. Hvem har udviklet systemet? (Hvis både interne enheder (kontor, afdeling) og private leverandører har bidraget til udviklingen af e-systemet angives alle):

DOKUMENTATION $\mathrm{i}$ form af kravspecifikation eller tilsvarende findes?
Ja $\square$
Nej $\square$

DOKUMENTATION af e-systemets tekniske udformning findes?

Ja $\square$

Nej $\square$

4b. Hvem har stået for driften af e-systemet? (Angiv både interne enheder og evt. private leverandører):

Navn

Periode

DOKUMENTATION af særlige forhold vedr. e-systemets drift findes?

Ja $\square$

Nej $\square$

\section{E-systemets beslutningsgrundlag}

Er systemet oprettet og drevet $\mathrm{i}$ henhold til beslutninger

i øverste organer (fx hovedbestyrelse)?

Ja $\square \quad$ Nej $\square$

Hvis Ja, hvilke?

DOKUMENTATION af beslutningsgrundlag findes?

Ja $\square$

Nej $\square$ 


\section{ARBEJDERMUSEET,}

6. E-systemets formål og indhold

6a. Beskriv e-systemets formål (Hvorfor er e-systemet oprettet? Hvilke oplysninger indgår i e-systemet? Hvilke behov skal e-systemet opfylde? Omfatter det hele virksomheden eller kun dele af? Er der tilføjet eller fjernet formål efter oprettelsen?):

6c. Indgår standardidentifikatorer i e-systemet?

CPR-numre

Ja $\square \quad$ Nej $\square$

SE-numre / CVR-numre

Ja $\square$

Nej $\square$

Postnumre

Kommunenumre før 1.1.2007

Ja $\square \quad$ Nej $\square$

Kommunenumre efter 1.1.2007

Ja $\square \quad$ Nej $\square$

Amtsnumre

Ja $\square$

Nej $\square$

Regionsnumre

Ja $\square$

Andre standardidentifikationer:

6d. Indgår termer fra journalplaner, emneordslister o.lign. i e-systemet?

Ja $\square$

Nej $\square$

DOKUMENTATION for betydningen af disse termer (forklaring $0 \mathrm{~g} / \mathrm{eller}$ referenceliste) findes?
Ja $\square \quad$ Nej $\square$ 


\section{ARBEJDERMUSEET\& ARBEJDERBEVÆGELSENS BIBLIOTEK OG ARKIV}

6e. Hvilke data tilføres sagerne/dokumenterne i e-systmet?

Vedlæg venligst en oversigt over de matadata (titel, dato, ophav, emneord o.lign.), der bliver tilknyttet sagerne/dokumenterne i e-systemet.

Baserer metadatasættet sig på dansk(e) eller international(e) standard(er)? $\quad$ Ja $\square \quad$ Nej $\square$

Hvis Ja, hvilke(n)?

\section{Tilvejebringelse af e-systemets metadata}

7a. Er metadata tilvejebragt ved indtastning?

Ja $\square$

Nej $\square$

Hvis Ja, besvares følgende:

Hvem har indtastet metadata i e-systemet?

Afdeling, kontor, personalegruppe

DOKUMENTATION for retningslinjer ved indtastning $i$ e-systemet ( $\mathrm{fx}$ brugervejledninger) findes?

7b. Indeholder e-systemet indscannede dokumenter?

Ja $\square$

Nej $\square$

DOKUMENTATION for scanningsprocedure findes?

Ja $\square \quad$ Nej $\square$




\section{ARBEJDERMUSEET\& ARBEJDERBEVAEGELSENS BIBLIOTEK OG ARKIV}

\section{Andre e-systemer}

8a. Har e-systemet afløst ældre e-systemer?

Ja $\square$

Nej $\square$

Hvis Ja, udfyldes nedenstående:

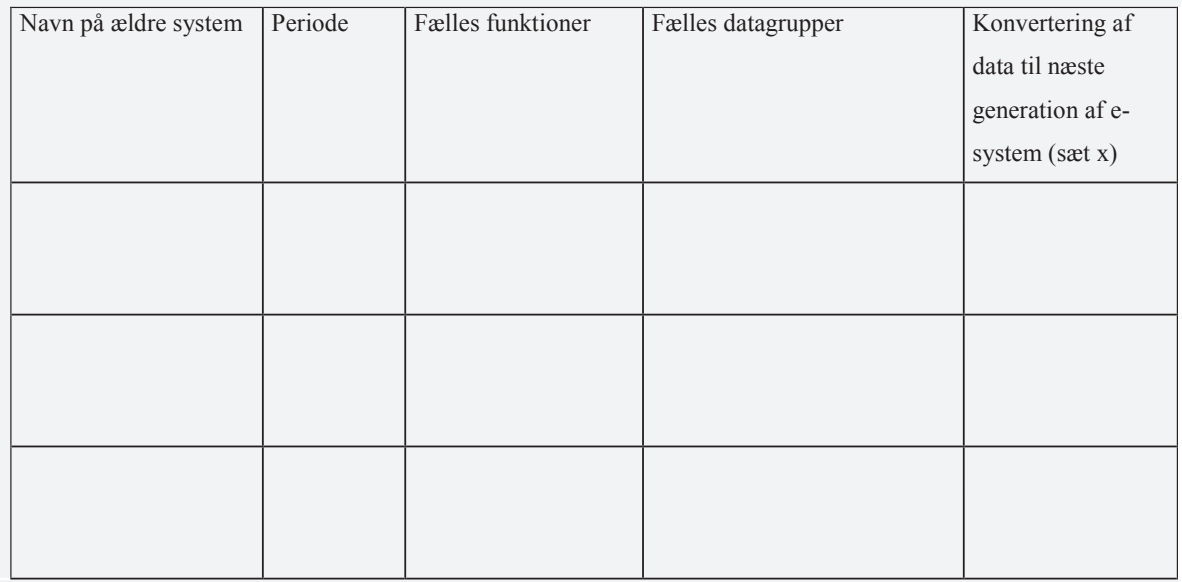

8b. Skal e-systemet afløses af nye systemer inden for en kendt fremtid?

Hvis Ja, udfyldes nedenstående:

\begin{tabular}{|l|l|l|l|l|}
\hline Navn på nye systemer & $\begin{array}{l}\text { Tidspunkt } \\
\text { for overgang }\end{array}$ & Fælles funktioner & Fælles datagrupper & $\begin{array}{l}\text { Konvertering af } \\
\text { data fra ældre e- } \\
\text { system (sæt x) }\end{array}$ \\
\hline & & & & \\
\hline & & & & \\
\hline
\end{tabular}

Hvis det nye system ikke er et e-system, så beskriv det nye system:

8c. DOKUMENTATION for e-systemets fælles funktioner med ældre og nyere systemer findes?

Ja $\square \quad$ Nej $\square$ 


\section{ARBEJDERMUSEET\& ARBEJDERBEVÆEGLSENS BIBLIOTEK OG ARKIV}

\section{9. Øvrige oplysninger om e-systemet}

9a. Er der slettet data i e-systemet?

Ja $\square$

Nej $\square$

Hvis Ja, besvares følgende:

Hvornår og i hvilken anledning er der slettet data?

DOKUMENTATION for sletningspraksis findes?

Ja $\square$

Nej $\square$

9b. Hvordan kontrolleres data (giv gerne flere svar)?

$\square$ Data kontrolleres ikke

Systembaseret kontrol

$\square$ Manuel kontrol

Kontrol for indholdsmæssige fejl

$\checkmark$ Kontrol for fejl i datatyper o.lign

$\square$ Andet:

DOKUMENTATION for egen kvalitetskontrol findes?

Ja $\square$

Nej $\square$

9c. Hvilke sprog anvendes i e-systemet?
$\square$ Dansk
$\neg$ Engelsk
$\square$ Andet:

\section{Publikationer, interne rapporter m.m. af og om data}

Forfatter, titel, år, evt. ISBN-nr., evt. URL:

Forfatter, titel, år, evt. ISBN-nr., evt. URL: 


\section{ARBEJDERMUSEET\& ARBEJDERBEVÆEGLSENS BIBLIOTEK OG ARKIV}

\section{Langtidsbevaring}

11a. Er der taget stilling til fremtidig langtidsbevaring af nuværende e-system?

Ja $\square$

Nej $\square$

Hvis ja, hvilken:

11b. Er evt. tidligere e-systemer langtidsbevaret?

Ja $\square$

Nej $\square$

Hvis Ja, hvordan:

Hvis nej, hvorfor:

12. Kontaktperson for evt. yderligere oplysninger

Kontaktperson (navn, e-mail-adresse): 